\title{
ANALYSIS OF PROFITABILITY AND OPERATIONAL EFFICIENCIES OF FRESH TOMATO MARKETING: EMPIRICAL EVIDENCE FROM OYO STATE NIGERIA

\author{
Olugbire, O.O., ${ }^{*}$ Aremu, F.J., ${ }^{2}$ Oke, D.O ${ }^{1}$ and Kolade, R.I ${ }^{1}$
} \\ 1.Forest Economics and Extension Department, Forestry Research Institute of Nigeria, Ibadan \\ 2. Department of Agricultural Economics, Obafemi Awolowo University, Ile-Ife.
}

*Corresponding author: olugbireolutoyin@gmail.com

\begin{abstract}
Although marketing is considered a very important aspect of agricultural production, it has been a neglected aspect of agricultural development plans and this has led to a situation where marketers of fresh tomatoes are not able to track their level of profitability and which invariably makes it difficult to attract prospective investor to the business. This study examines empirically profitability and operational efficiencies of fresh tomato marketing in South Western Nigeria. The study employed primary data using structured questionnaires to collect information from 100 randomly selected fresh tomato marketers in the study area. Data collected were analyzed using descriptive statistics; gross margin and marketing efficiency analytical techniques. The result of the analysis revealed that for every $\$ 100$ invested in fresh tomato trading in the study area, wholesalers, retailers and wholesalers/retailerrealized profit of $\$ 28.00,118.00$ and 258.00 respectively while the average operational efficiencies of wholesalers, retailers and wholesalers/retailer are $60.85 \%, 74.00 \%$ and $80.50 \%$ respectively. These positive and size of profits obtained for each fresh tomato marketing institutions is an indication that these institutions were able to recover their operating expenses; hence, marketing fresh tomato in the study area is profitable and efficient.
\end{abstract}

Keywords: Wholesalers; retailers; profitability; operational efficiencies.

https://dx.doi.org/10.4314/jafs.v18i2.8

\section{INTRODUCTION}

Marketing of tomatoes is a very good source of employment both at the urban and rural levels for the rapidly increasing population size of Nigerians who earn their living as producers, transporters, marketers, middlemen and the professional packing men. Excess production through finished products such as tomato "puree", "paste", and "ketch up" could be exported to the foreign countries and thus gives Nigeria a good foreign exchange (Salau and Salman 2017; Amao, 2010). Aminu and Musa, (2007) reported that the bulk of tomato production lies in the Northern part of the country especially areas around Jigawa and Kano States. Some places in the southern part such as Oyo State also produce some amount of tomatoes but the urban centres mostly in the south 
Journal of Agriculture and Food Sciences $\quad$ Olugbire, O.O., Aremu, F.J., Oke, D.O and Kolade, R.I Volume 18, Number 2, October 2020, pp $109-119$

constitute the major consumption areas and market in those areas are the common outlets for all the production zones (Sanusi and Dada, 2016).

In recent times, Federal and State governments of Nigeria have made it a matter of policy attention to diversify the present over dependence of the country's economy on oil by focusing on Agriculture and entrepreneurial development of Nigerians. To this end, more people are going into the production of fruits and vegetables such as citrus, water lemon, tomatoes, vegetables among others, which in the long run necessitated the springing up of more tomato markets and participation of more people in fresh tomato marketing in Nigeria (Aremu, 2011). Though marketing is considered very important, it has been a neglected aspect of agricultural development plans (Akura et al, 2018) and this has led to a situation where marketing tomatoes by farmers and other stakeholders involve lot of cost which invariably influence its market performance. This study hence examined the profitability performance of the participants. Though much work exists on fresh tomato production, little is known on its marketing profitability and operational efficiency of the participants which this study aims at filling such gaps and this study will also add to the existing literatures on marketing of fresh tomato. In order to assess how efficient fresh tomato market is being operated among the actors, critical economic evaluation of institutions involved is essential in the framework of efficiency. (Folayan et al. 2007).

Efficiency ratio, profitability ratio and operational efficiencies have been used to appraise fresh tomato marketing institutions in Nigeria (Folayan et al. 2007: Umar and Yaro, 2017; Mauyo et. al. 2007). Operational efficiency is a measure of comparison of the least marketing cost incurred by a firm (most efficient firm) in an industry to the marketing cost incurred by each of the firm whose performance is being rated in the industry- (Folayan et al., 2007; Mauyo et. al. 2007). The lesser the marketing cost of the firm, the more efficient is the operation when compared with other firms in the marketing industry (Umar and Yaro, 2017; Folayan, et al.,2007).

\section{METHODOLOGY}

\section{Study area}

The study was carried out in Oyo state, South-West Nigeria. Thestudy area has heterogeneous population of Yoruba, Igbo and Hausa.The state lies between longitude $3^{0}$ and $5^{0} \mathrm{E}$ and latitude 7 and $8^{0} \mathrm{~N}$ and cover an area approximately $26,500 \mathrm{~km}^{2}$ and has a total population of 5,591,585 (NPC, 2006). Oyostate consists of 33 local government areas. The state covers a total of 27,249 square kilometers of land mass and it is bounded in the south by Ogun state, in the north by Kwara state, in the west partly by Ogun state and partly by Benin republic, and in the east by Osun state.

The state has two climatic seasons which are the dry season that occurs between November and March and the rainy season that occur between April and October. The climate in the State favours the cultivation of crops like maize, yam, cassava, millet, rice, plantains, cocoa, palm produce, cashew, etc. Agriculture has been the backbone of the economy of the States providing income and Journal of the Faculty of Agriculture and Veterinary Medicine, Imo State University Owerri website: www ajol.info; Attribution: Non-commercial CC BY-NC 
Journal of Agriculture and Food Sciences $\quad$ Olugbire, O.O., Aremu, F.J., Oke, D.O and Kolade, R.I Volume 18, Number 2, October 2020, pp $109-119$

employment opportunities for over $70 \%$ of the population. The States are significantly producers of arable crops in Nigeria.

\section{Sampling technique}

Multi stage random sampling technique was used to select respondents in the study area. Firstly, four local government areas were purposively selected because they have the largest fresh tomato markets which serve as a meeting point for wholesalers, middlemen, and the retailers who are actively engaged in buying and selling of tomatoes in the state. The second stage involved the purposive selection of one major market in each of the four local governments, which were Sasa market (Akinyele Local Government), Akesan market, (Oyo East Local Government), Bodija market (Ibadan North Local Government) and Sabo market (Ogbomoso North Local Government). In the third stage forty wholesalers were randomly selected as follows: 20 from Sasa market, 10 from Sabo market, 8 from Bodija market and 2 from Akesan market. Sixty retailers were also randomly selected as follows: 20 from Bodija market, 20 from Akesan market, 10 from Sabo market and 10 from Sasa market. However, in the course of pre-test field survey, some respondents were discovered to be both wholesalers and retailers (mostly middlemen) and so interview was conducted for 20 from this category of respondents making the total number of respondents used for the study to increase to 120 .

\section{Analytical Technique}

To evaluate the profitability of fresh tomato in the study area, profitability ratio and gross margin analysis, were used for the analysis; while marketing efficiency model were used to examine the fresh tomato operational efficiency in the study area.

\section{Gross margin analysis and Profitability Ratio}

The gross margin was used to determine the profit margin of tomatoes marketing and was specified as follows (Aremu, 2011):

$\mathrm{GM}=\mathrm{TR}-\mathrm{TVC}$

Profitability ratio $(P R)=\Pi / \mathrm{TC}=\mathrm{G} \cdot \mathrm{M} / \mathrm{TVC}$

$\mathrm{TC}=\mathrm{TVC}+\mathrm{TFC}$

Where:

$\mathrm{GM}=$ Gross Margin

$\Pi=$ Net Profit/basket traded ( $)$

TR = Total Revenue/basket sold (

TVC $=$ Total variable Cost $($ )

$\mathrm{TC}=$ Total Cost/basket sold ( $)$

$\mathrm{P}=$ Price of a unit basket of fresh tomatoes sold (N)

$\mathrm{Q}=$ Quantity of fresh tomatoes/basket sold (basket)

Note: All costs and revenues are measured in naira per basket of tomatoes traded

Journal of the Faculty of Agriculture and Veterinary Medicine, Imo State University Owerri website: www ajol.info; Attribution: Non-commercial CC BY-NC 
Journal of Agriculture and Food Sciences $\quad$ Olugbire, O.O., Aremu, F.J., Oke, D.O and Kolade, R.I

Volume 18, Number 2, October 2020, pp $109-11.9$

\section{Measure of market performance of fresh tomato marketing}

Marketing efficiency was used also to ascertain the performance of fresh tomatoes market. Efficiency in the agricultural industry is the most frequently used measure of market performance. Efficient marketing optimizes the ratio between inputs and outputs. Marketing inputs here include the resources used in marketing tomatoes, such as: transport costs, loading and off-loading cost, commission, local government revenue, labour used, packaging and other transaction cost. Whereas marketing output is the benefits or satisfaction created or the value added to the commodity as it passes through the marketing system. Efficiency can be expressed in physical or monetary terms, if monetary terms are used, the efficiency concept becomes a ratio of benefits to cost or if in physical, it becomes output to input used. Following Adejobi et al., (2011) the marketing efficiency of tomatoes is specified as:

Marketing Efficiency $(\mathrm{ME})=\underline{\text { Total Revenue }}$ X 100

$$
\text { Marketing cost }
$$

When $\mathrm{ME}=100 \%$, it implies that the participant just recovered the cost incurred in carrying out the marketing services. This is breakeven point for the marketer.

ME $>100 \%$ implies that the participant covered the cost of marketing and made a margin above the $100 \%$. This is profit for the marketer

$\mathrm{ME}<100 \%$ indicates that the participant is operating at a loss.

Accordding to (Umar and Yaro, 2017), efficiency value that falls below 50\% is considered inefficient, while values above $50 \%$ is efficient.

\section{RESULTS AND DISCUSSION}

\section{Socio-economic characteristics of the respondents}

Table 1 shows the age distribution of respondents. Majority of the wholesalers $(37.5 \%)$ were within the age range of 20-30 years and most of the retailers (43.3\%) were within 31-40 years. A total of $87.5 \%$ of the wholesalers and $93.3 \%$ of retailers were thus aged below 50 years. This indicates that most of fresh tomato marketers were young and were in their active age in terms of marketing activities. Hence, given the needed resources, the marketers have high potentials to attain a high level of profitability. The relatively young age of these respondents should, ceteris paribus have positive impacts on marketing size, revenue and ability to take risks. This confirms Adejobi et al., (2011) who reported that most fresh tomato marketers are in their active age. While 93.3\% of the retailers were females and the remaining $6.7 \%$ of the retailers being males. This shows that tomato marketing is gender biased which may be due to differences in marketing activities at wholesales and retails level. Since the wholesales is riskier, involves much travelling 
Journal of Agriculture and Food Sciences $\quad$ Olugbire, O.O., Aremu, F.J., Oke, D.O and Kolade, R.I Volume 18, Number 2, October 2020, pp $109-11.9$

and absent from home for several days while retailing is almost sedentary, allows the female gender not to be idle at home, and also able to take care of their families (Aremu, 2011).

Only $25 \%$ of wholesales had family size of less than four. $65 \%$ had family size between 4 and 8 while the rest had more than 10 . However, $8.3 \%$ of the retailers had family size of less than 4 , while $86.7 \%$ had between 4 and 8 . This confirms similar findings, from other studies conducted in the south western region of Nigeria (Oluwasola, 2010, Oluwasola and Alimi, 2008).

About $10 \%$ of the wholesalers did not go to school, $20 \%$ had only primary education, while $70 \%$ completed secondary education. For the retailers, $21.7 \%$ did not go to school at all. $41.7 \%$ had primary education, $26.6 \%$ had secondary education while only $10 \%$ had informal education.

Clearly, the level of education among the wholesalers is fair whereas very low among the retailers. Educational status of the marketers has a lot to do with individuals' standard of living because high educational status provides opportunities that are not easily obtained by the illiterates. It also enables the individual to make efficient use of his income and resources available to him. This study confirms Oluwasola (2010) who reported that low level of education among the retailers could have serious implications on their ability to access information, use new technological innovations and even access or procure credit from formal financial institutions. Fifty percent of the wholesalers had 10 years of marketing experience, 25\% had 1-20 years experience while the remaining $25 \%$ had more than 20 years of marketing experience. About forty six percent of the retailers had 1-10 years of marketing experience, 33.3\% had between 11-20 years of experience while $20 \%$ had more than 20 years of experience. This shows that marketing experience is a vital aspect of tomato marketing and it is not a business that anybody can just venture to. This agree with Adejobi et al. (2011) who stated that long experience enable the marketers to acquire indigenous methods of preserving fresh tomatoes which helps to reduce the percentage loss due to damage.

\section{Cost and Return Analysis}

The result of cost and return analysis as a measure of profitability among the marketing institutions showed that wholesalers recorded an average variable cost and total revenue of $141,200.00$ and $\$ 180,000.00$ respectively with an average gross margin of 38,800 . Also, the average variable cost and total revenue for retailers were $\$ 279,000$ and $\$ 330,000$ respectively with an average gross margin of 51,000 while the wholesaler/retailer recorded an average variable cost and revenue of 25,976.7 and 66,972.2 respectively with gross margin of 40,995.5

The computed profitability ratio as presented in table 2 for wholesalers, retailers and wholesalers/retailers are $0.275,0.183$ and 1.58 respectively. This indicates that for every 100 invested by wholesalers, retailers and wholesalers/retailer each gained 27.50, 18.30 and N158.00 respectively in the study area. Hence, fresh tomato marketing is confirmed to be profitable in conformity with the earlier findings under cost and return analysis. It also agrees with 
Journal of Agriculture and Food Sciences $\quad$ Olugbire, O.O., Aremu, F.J., Oke, D.O and Kolade, R.I Volume 18, Number 2, October 2020, pp $109-119$

Umar and Yaro, (2017) who reported that marketing of fresh tomato is a profitable in the study area.

The size and positive values of profit margin obtained confirmed to the fact that fresh tomato marketing institutions were able to cover their operating expenses with a significance level of profit level obtained from the study area.

\section{Marketing Efficiency of Fresh Tomato Marketing}

\section{Efficiency ratio}

The estimated efficiency ratios for the wholesalers, retailers and wholesaler/retailers were 1.275, 1.183 and 2.58 respectively. As the efficiency ratios of each marketing institutions were greater than unity is an indication that their operations were efficient.

\section{Marketing efficiency of fresh tomatoes}

Table 3 presents the results of the marketing efficiencies of fresh tomatoes marketers. The distribution ranged from $40.0 \%$ which denote inefficiency to $100 \%$ which represents maximum efficiency for the wholesalers; from $54.00 \%$ for the retailers and $76.00 \%$ for those marketers that performed the roles of both wholesalers and retailers at the same time while their average efficiencies were $60.85 \%, 74.00 \%$ and $80.50 \%$ respectively. The results implies that since majority of wholesalers operate on the average marketing efficiency level, the wholesalers can be said to be efficient in terms of using minimum resources to achieve maximum output This therefore confirms Aremu (2011) who reported that most of the wholesalers in the study area reduce marketing cost by using alternative resources that are cheaper though crude such as transporting tomato baskets from the North through Petrol tankers and this gives higher profit margin. The fact that the estimated operational efficiencies (average efficiency values) for the three marketing institutions were greater than $60 \%$ is an indication that fresh tomato marketing was efficient at these levels in terms of achieving least marketing cost in carrying out fresh tomato trading in the study area.

\section{CONCLUSION}

This paper used cost and return analysis and measures of market efficiency to examine the operational performance of marketing of tomatoes in the study area. The results of the analysis revealed that gross margin of the wholesalers; retailers and wholesaler/retailers showed that fresh tomato marketing is profitable. Using the profitability ratio, it was further discovered that for every $\$ 100$ incurred by the wholesalers, retailers and wholesaler/retailer as institutions involved in fresh tomato trading realized $27.5,18.3$ and 258.0 respectively. This indicates that the operations of fresh tomato marketing institution are efficient and profitable since efficiency and profitability ratios are positive while the magnitude of percentage operational efficiencies for each of the institutions was more than 60 percentages but it is those marketers that can serve as both Journal of the Faculty of Agriculture and Veterinary Medicine, Imo State University Owerri website: www ajol.info; Attribution: Non-commercial CC BY-NC 
Journal of Agriculture and Food Sciences $\quad$ Olugbire, O.O., Aremu, F.J., Oke, D.O and Kolade, R.I

Volume 18, Number 2, October 2020, pp $109-119$

wholesalers and retailers that take the bulk of the profit. This finding implies that fresh tomato marketing has the potential of improving the standard of living of the actors such that unemployment problem could be alleviated and income evenly distributed considering the profitability level recorded.

It is therefore recommended that policies that will provide enabling environment for efficient and cost-effective marketing of tomatoes should be promoted in the study area so that prospective investors can be encouraged to invest in tomatoes marketing chain in the study area. Finally, there should be increase in the awareness of the prospect of Shea butter marketing enterprise among educated youths and young adults in Nigeria. This will ensure continuity of the business as well as maximization of input-output ratio of the bus.

Journal of the Faculty of Agriculture and Veterinary Medicine, Imo State University Owerri website: www ajol.info; Attribution: Non-commercial CC BY-NC 
Journal of Agriculture and Food Sciences $\quad$ Olugbire, O.O., Aremu, F.J., Oke, D.O and Kolade, R.I

Volume 18, Number 2, October 2020, pp $109-119$

\section{REFERENCES}

Adejobi, K.B., Famaye, A.O., Adeniyi, D., Orisajo, S., and Adeyemi, E.A. (2011). Effect of cocoa pod husk ash and goat dung on nutrient content and growth performance of cashew (Anacardium occidentale). Advances in Environmental Biology, 5(7): 1536-1542.

Akura, D., Nyiatagher, Z., and Ocholi A. (2018). Efficiency and profitability of citrus marketing in Benue State of Nigeria. FUNAI Journal of Accounting, Business and Finance 3(1):153-168

Amao, A.O. (2010). Price analysis of tomato produce in rural and urban market in Oyo State. An Unpublished Thesis, Department of Agricultural Economics, University of Ibadan.

Aminu, A., and Musa, S.A. (2007). Tomato chain analysis in Kano River irrigation project, Nigeria. Department of Agricultural Economics and Extension, Bayero University, Kano.

Aremu, F.J. (2011). Marketing of fresh tomatoes in Oyo State. An Unpublished Thesis, Department of Agricultural Economics, Obafemi Awolowo University, Ile Ife, Nigeria.

Folayan, J.A; Oguntade, A.E. and Ogundari, K. (2007). Analysis of profitability and operational efficiency of cocoa marketing: empirical evidence from Nigeria. Journal of Social Science, 15(2):197-199. https://doi.org/10.1080/09718923.2007.11892582

Mauyo, L., Okalebo, J., Kirkby, R., Buruchara, R., Ugen, M., Mengist, C., Anjichi, V. and Musebe, R. (2007). Technical efficiency and regional market integration of cross-border bean marketing in western Kenya and eastern Uganda. African Journal of Business Management Issue 1.77-84.

National Population Commission (NPC) (2006). A blueprint of 2006 National Census Abuja, Nigeria.

Ogbomo, L. (2011). Comparison of growth, yield performance and profitability of tomato under different fertilizer types in humid forest ultisols. International Research Journal of Agricultural Science and Soil Science. 1(18):332-338

Oluwasola, O. (2010). Stimulating rural employment and income for cassava (Manihot sp.) processing farming households in Oyo State, Nigeria through policy initiatives. Journal of Development and Agricultural Economics (2):18-25.

Oluwasola, O. and Alimi, T. (2008). Determinants of Agricultural Credit Demand and Supply Among Small-Scale Farmers in Nigeria. Outlook on Agriculture (37): 185-193. DOI $10.5367 / 000000008785915421$.

Salau, S. and Salman, M. (2017). Economic analysis of tomato marketing in Ilorin metropolis, Kwara State, Nigeria. Journal of Agricultural Sciences (62): 179-191. DOI 10.2298/JAS1702179S.

Journal of the Faculty of Agriculture and Veterinary Medicine, Imo State University Owerri website: www ajol.info; Attribution: Non-commercial CC BY-NC 
Sanusi, M. M. and Dada, O.D. (2016) Profitability analysis of marketing tomato in Odeda local government area of Ogun State, Nigeria. Ife Journal of Agriculture, 34(2): 65-82.

Umar, S.D. and Yaro, A.M. (2017). profitability analysis of fresh tomato retail marketing in some major markets of Kano State, Nigeria. International Journal of Research in Science 3(4):13-24. https://doi.org/10.24178/ijrs.2017.3.4.13 
Olugbire, O.O., Aremu, F.J., Oke, D.O and Kolade, R.I $109-120$

Journal of Agriculture and Food Sciences $\quad$ Olugbire, O.O., Aremu, F.J., Oke, D.O and Kolade, R.I Volume 18, Number 2, October 2020, pp 109 - 11 .

\section{APPENDIX}

Table 1: Socio-economic characteristics of respondents.

\begin{tabular}{|c|c|c|c|c|c|c|}
\hline \multirow{2}{*}{$\begin{array}{ll}\begin{array}{l}\text { Socio- } \\
\text { characteristics }\end{array} & \text { economic } \\
\end{array}$} & \multicolumn{2}{|c|}{ Wholesalers } & \multicolumn{2}{|c|}{ Retailers } & \multicolumn{2}{|c|}{ Wholesalers-Retailers } \\
\hline & Freq & $\%$ & Freq & $\%$ & Freq & $\%$ \\
\hline \multicolumn{7}{|l|}{ Age of respondents (Years) } \\
\hline$<20$ & 3 & 7.5 & 3 & 7.5 & 2 & 10 \\
\hline $20-30$ & 15 & 37.5 & 8 & 13.3 & 2 & 10 \\
\hline $31-40$ & 8 & 20.0 & 26 & 43.3 & 5 & 25 \\
\hline $41-50$ & 9 & 22.5 & 19 & 31.7 & 6 & 30 \\
\hline$>50$ & 5 & 12.5 & 4 & 6.7 & 5 & 25 \\
\hline Total & 40 & 100 & 60 & 100 & 20 & 100 \\
\hline \multicolumn{7}{|l|}{$\begin{array}{l}\text { Gender distribution of } \\
\text { respondents }\end{array}$} \\
\hline Male & 80 & 80.0 & 4 & 6.7 & 5 & 25 \\
\hline Female & 20 & 20.0 & 56 & 93.3 & 15 & 75 \\
\hline \multicolumn{7}{|l|}{ Family size of respondents } \\
\hline $1-4$ & 10 & 25.0 & 5 & 8.3 & 5 & 25 \\
\hline $5-6$ & 15 & 37.5 & 40 & 66.7 & 12 & 60 \\
\hline $7-8$ & 11 & 27.5 & 12 & 20.0 & 2 & 10 \\
\hline$>9$ & 4 & 10.0 & 3 & 5.0 & 1 & 5 \\
\hline \multicolumn{7}{|l|}{$\begin{array}{l}\text { Level of education of } \\
\text { respondents }\end{array}$} \\
\hline No formal education & 4 & 10.0 & 13 & 21.7 & 2 & 10 \\
\hline Completed primary school & 8 & 20.0 & 25 & 41.7 & 5 & 25 \\
\hline $\begin{array}{l}\text { Completed secondary } \\
\text { school }\end{array}$ & 28 & 70.0 & 16 & 26.6 & 12 & 60 \\
\hline Completed tertiary school & - & - & - & - & 1 & 5 \\
\hline $\begin{array}{l}\text { Marketing experience } \\
1-10\end{array}$ & 20 & 50.0 & 28 & 46.7 & 7 & 35 \\
\hline $11-20$ & 10 & 25.0 & 20 & 33.3 & 8 & 40 \\
\hline More than 20 & 10 & 25.5 & 12 & 20 & 5 & 25 \\
\hline $\begin{array}{l}\text { Monthly Income } \\
<10,000\end{array}$ & 10 & 25.0 & 10 & 16.7 & - & \\
\hline $10,000-15,000$ & 7 & 17.5 & 20 & 33.3 & 2 & 10 \\
\hline $16,000-20,000$ & 20 & 50.0 & 23 & 38.3 & 3 & 15 \\
\hline$>20,000$ & 3 & 7.5 & 7 & 11.7 & 15 & 75 \\
\hline
\end{tabular}

Source: Field survey, 2014

Journal of the Faculty of Agriculture and Veterinary Medicine, Imo State University Owerri website: www ajol.info; Attribution: Non-commercial CC BY-NC 
Journal of Agriculture and Food Sciences $\quad$ Olugbire, O.O., Aremu, F.J., Oke, D.O and Kolade, R.I Volume 18, Number 2, October 2020, pp $109-119$

Table 2: Summary distribution of cost and return analysis of fresh tomato marketing

Parameters Wholesalers Retailers Wholesaler/Retailers

\begin{tabular}{lccc}
\hline Total Variable Cost & $141,200.0$ & $279,000.0$ & 25976.7 \\
Total Revenue & $180,000.0$ & $330,000.0$ & 66972.2 \\
Gross Margin & $38,800.0$ & $51,000.0$ & 40995.5 \\
Profitability Ratio & 0.275 & 0.183 & 1.58 \\
Efficiency Ratio & 1.275 & 1.183 & 2.58 \\
\hline
\end{tabular}

Source: Field survey 2014

Table 3: Percentage distribution of marketing efficiency at wholesale, retail and wholesale/retail levels.

\begin{tabular}{lccc}
\hline Efficiency Scores & Wholesalers & Retailers & Wholesaler/Retailer \\
\hline Minimum Efficiency & $40.0 \%$ & $54.00 \%$ & $76.00 \%$ \\
Maximun Efficiency & $100.0 \%$ & $100.0 \%$ & $100.00 \%$ \\
Average Efficiency & $60.85 \%$ & $74.00 \%$ & $80.50 \%$ \\
\hline
\end{tabular}

Source: Calculations from field survey, 2014 